\title{
Alzheimer's Disease: Environmental Factors and Etiologic Hypotheses
}

\author{
Denyse Gautrin and Serge Gauthier
}

\begin{abstract}
A review of published reports on conventional and unconventional viruses, aluminum, neurotoxic metals and trace elements, neurotoxins of biological origin and immune systems, suggest that environmental factors, possibly multiple ones, play a significant role in the etiology of Alzheimer's disease. A complex interaction between genetic predisposition to this illness, natural aging processes, environmental factors over a life-time exposure and pathological alterations of the host immune system is proposed.
\end{abstract}

RÉSUMÉ: Maladie d'Alzheimer: facteurs de l'environnement et les hypothèses sur l'étiologie Notre revue des rapports publiés sur les virus conventionnels et non-conventionnels, l'aluminium, les métaux neurotoxiques et éléments rares, les neurotoxines biologiques et les systèmes immunitaires, suggère que des facteurs environnementaux, possiblement multiples, jouent un rôle significatif dans l'étiologie de la maladie d'Alzheimer. Une interaction complexe entre une prédisposition génétique à cette maladie, les mécanismes du vieillissement naturel, les facteurs environmentaux au cours de la vie et des changements pathologiques du système immunitaire de l'hôte est proposée.

Can. J. Neurol. Sci. 1989; 16:375-387

\section{Contents}

Viruses

Studies in humans

Epidemiological case-control studies

Sero-epidemiological studies of common viruses in AD

Studies on human brain tissue

Studies on animal models

Aluminum

Case-control studies

Ecological studies

Hemodialysis and dementia

Occupational exposure

Biological markers of aluminum exposure in man and in animal

Neurotoxic metals and trace elements

Lead

Tin

Manganese

Mercury

Zinc

Neurotoxins of biological origin

Immune system dysfunction

Case-control studies of $A D$ in relation to diseases of the immune system

Studies of cellular immune activity in patients with $\mathrm{AD}$

Conclusion
Both genetic and environmental factors have been evoked to explain the etiology of $A D$, but as with several diseases, the relative importance of these factors is difficult to establish. Environmental factors most often hypothesized to be associated with Alzheimer's disease (AD) are viruses and aluminum. Neurotoxins of chemical or biological origin have also been suggested as potential etiological agents. Furthermore, immune function deficits may be directly or indirectly involved in the pathogenesis of $\mathrm{AD}$.

The purposes of this review paper are first to examine the current evidence for the involvement of environmental factors in $\mathrm{AD}$ and, secondly, to determine the reliability of measures of biological markers of putative environmental risk factors and assess to what extent atypical levels of biological markers have been shown to be associated with the disease.

\section{ViRUSES}

An infectious hypothesis of Alzheimer's disease has been suggested by clinical and pathological similarities with degenerative neurological disorders (eg. kuru, Creutzfeldt-Jacob disease, Gerstmann-Straussler syndrome and scrapie) that have been shown to be transmissible.1,2 These forms of transmissible

From the McGill Centre for Studies in Aging, McGill University, Montreal (D.G., S.G.); INRS - Santé (D.G.).

Reprint requests to: Dr. Serge Gauthier, 1650 Cedar Ave., Montreal, Quebec, Canada H3G 1A4 
encephalopathies are caused by agents that have been designated as unconventional viruses. There is no evidence that AD is transmitted between humans and all attempts to transmit the disease to non-human primates have failed except in two cases. ${ }^{3}$ Replication of these positive findings have been impossible. ${ }^{4}$ These negative results may be due to the adaptation of an unconventional virus to human species and to low titers of viruses present in AD brain tissue. Suggestive positive evidence for the viral hypothesis is limited to two findings: i) extracts of human brains have been shown to induce neurofibrillary tangles (NFT) with paired helical filaments in vitro in human embryonic neuroblasts; ${ }^{5}$ these results however have not been replicated; ii) some similarities between the infectious agent in scrapie and the amyloid core in senile plaques of $\mathrm{AD}$ patients were described by Prusiner. ${ }^{6}$

It has also been proposed that common viruses may be involved in the etiology of neurodegenerative brain diseases and this may be associated with a particular genetic predisposition. Indeed a number of common viruses are known to cause acute infections of the central nervous system (CNS) and the peripheral nervous system (PNS), these include mumps, varicella zoster, measles, herpes simplex, rubella viruses and entero-viruses.? According to a review by Esiri ${ }^{8}$ on the role of typical and atypical viruses in the etiology of $A D$, two pathological characteristics of AD support the hypothesis of the involvement of common viruses in this condition. The first is the localisation of NFT in the olfactory pathways and in areas of the cortex connected to those pathways suggesting the possibility of an environmental factor whose route of entry would be the nose or the nasopharynx. The second are the NFT themselves which are common to diseases caused or presumably caused by viruses. These are herpes simplex virus (HSV) encephalitis and parkinsonism occurring after encephalitis lethargica.

\section{Studies in Humans: Epidemiological Case-Control Studies}

The viral hypothesis has been examined in a number of casecontrol studies. ${ }^{9-13}$ Specific questions have borne directly on antecedent infections (eg. meningitis, encephalitis, herpes infection or influenza during World War I) or indirectly by ingestion of animal brain, raw meat and raw seafood, by animal contacts (eg. pets, livestock, and wildlife), by travel in specific geographic areas, by blood transfusion and by service in the Armed Forces in the Orient or South Pacific.

The results of these studies are presented in Table 1. Heyman et al, $"$ found an odds ratio (OR) of 3.33 (not reaching significance) for herpes zoster. Amaducci et $\mathrm{al}^{9}$ found a significant $\mathrm{OR}$ for HSV type II when cases were compared to hospital controls. Shalat et al ${ }^{13}$ have reported an OR of 3.2 for antecedent meningitis, but this OR was not statistically significant. Amaducci et $\mathrm{al}^{9}$ found a significant $O R$ for contact with any pet; if the pet was specified, only contact with dogs was significant. In two other studies where this information was collected, no relation was found with this type of exposure. These results are inconclusive and the hypothesis that a virus may be a causal factor has not been confirmed but cannot be ruled out on the basis of the data currently available. In the studies reported above, exposure to potential sources of viral infection has not been controlled for the area of residence (e.g. rural vs urban). In one study contact with animals, livestock in particular, was more frequent among controls; however, selection of subjects was biased, controls being more likely in rural areas compared to cases. 10

Possible explanations for the small number of significant positive associations between putative risk factors and $A D$ in the case-control studies mentioned are: i) the information on remote events and from reports by surrogate respondants is of poor quality; ii) the search for an infectious agent was done over an inappropriate time period of life; and iii) in some instances the approach to assess potential viral infection was indirect (i.e. ingestion of raw meat). In the studies reported, information was not collected on the occurrence of common childhood infectious diseases.

\section{Sero-epidemiological Studies of Common Viruses in AD}

There are only a few studies in which viral antibody titers in cerebrospinal fluid (CSF) and serum have been measured in demented patients and compared to those in controls. High titers of HSV and cytomegalovirus (CMV) were found in cases with senile dementia and multi-infarct dementia by Lycke et al. ${ }^{14}$ These findings however were not replicated by Lord et al ${ }^{15}$ who showed increased titers of serum antibodies to adenovirus. These results do not relate specifically to the role of common viruses in the etiology of $A D$ since no distinction was made between vascular and degenerative dementia.

Three studies were restricted to AD patients. Whalley et al ${ }^{16}$ measured serum antibodies to a number of viruses and bacteria in patients with presenile dementia $(n=14)$ but no associations were demonstrated. Similar CMV antibody titers were found in both patients and controls. High levels of CMV in the patients were correlated with having the HLA-B 15 histocompatibility antigen, known to have a weak association with $\mathrm{AD}$. Renvoize et al ${ }^{17}$ studied serum antibody titers to nine infectious agents (Adenovirus, Chlamydia group B, Coxiella burnettii, CMV, HSV, Influenza A, Influenza B, measles and Mycoplasma pneumoniae). The group of subjects studied included 33 patients with a clinical diagnosis of $\mathrm{AD}$ and 28 non-demented patients with functional psychiatric disorders. High titers were found in $\mathrm{AD}$ for HSV, Influenza A, Influenza B, and measles; however, none of the differences were statistically significant.

These studies need to be replicated on cases with a diagnosis of "probable AD" according to the NINCDS-ADRDA criteria 18 and normal controls matched for age and sex.

\section{Studies on Human Brain Tissue}

During the last decade, a number of studies have been performed on human brain tissue to investigate the possible involvement of a common virus in the etiology of $\mathrm{AD}$ and other dementing illnesses, with particular emphasis on HSV. The results obtained in seven recent studies are summarized in Table 2. The groups of cases consisted either of AD patients only, 7,19,20 of patients with dementia caused by psychiatric disorders including $A D, 21$ or of demented patients without specification of the cause. ${ }^{22}$ The largest sample of AD brain specimens included 18 brains, ${ }^{19}$ compared to the brains of five normal controls. The presence of HSV-1, measles virus, adenovirus-7 and/or a number of RNA and DNA viruses has been investigated by several research groups ${ }^{20-24}$ each using one or more different techniques namely: i) molecular or solution hybridization with a reported low sensitivity of 0.1-0.5 to 76 genome-equiva- 
lent of virus per cell; ii) in situ hybridization, a high sensitivity technique; iii) immunohistochemistry. In combination with the solution hybridization, DNA or RNA extracts of selected regions of the brain were used for detection of viral genome. The brain regions were chosen in accordance with current knowledge of the sites where neuropathological signs of AD are predisposed to occur (e.g. the limbic system). In situ hybridization is done using brain smears or prepared slices of brain tissue.

Molecular hybridization gave negative results in attempts to identify the presence of viral genome for HSV-1.22 A positive finding was the identification of measles nucleic acids in substantia innominata RNA from an AD case. When tissue samples of the temporal cortex were assayed for the presence of HSV surface antigens using the antibody-enzyme method, a positive reaction occurred in only one $A D$ case. ${ }^{20}$ Esiri, ${ }^{24}$ on the other hand, reported positive reactions in $12 \mathrm{AD}$ patients when the test material was taken from the dentate fascia of the hippocampus. Using radio-labelled HSV-1 probes for in situ hybridization, Sequiera et al ${ }^{21}$ was able to detect the viral genome in three out of four cases with chronic psychiatric illness and in neither of two patients with acute psychiatric conditions. Walker et al23 were unable to detect the viral genome in areas of the brain histopathologically involved in AD from confirmed cases. On the other hand they were able to demonstrate the high sensitivity of in situ hybridization since it revealed the presence of HSV-1 in the trigeminal ganglia and showed that cells with latent infection could be detected in tissue of individuals with a prior HSV infection but with no clinical signs of the disease before death.

Overall, there are conflicting results regarding the presence of HSV DNA in target areas for AD pathology, and positive findings are rare. Possible explanations may be the low titers of viruses and the difficulty of choosing appropriate brain areas for sampling specimens.

Esiri ${ }^{8}$ has reviewed the evidence for the parallelism between HSV encephalitis and AD in terms of anatomo-pathological considerations and discussed results of studies performed on brains of $\mathrm{AD}$ cases and controls to uncover relations between HSV infection and AD.

A hypothesis was proposed by Ball25 on the possible association between HSV infection and the development of AD. Based

Table 1: Possible Sources of Viral Infection Investigated in Case-Control Studies of Alzheimer's Disease

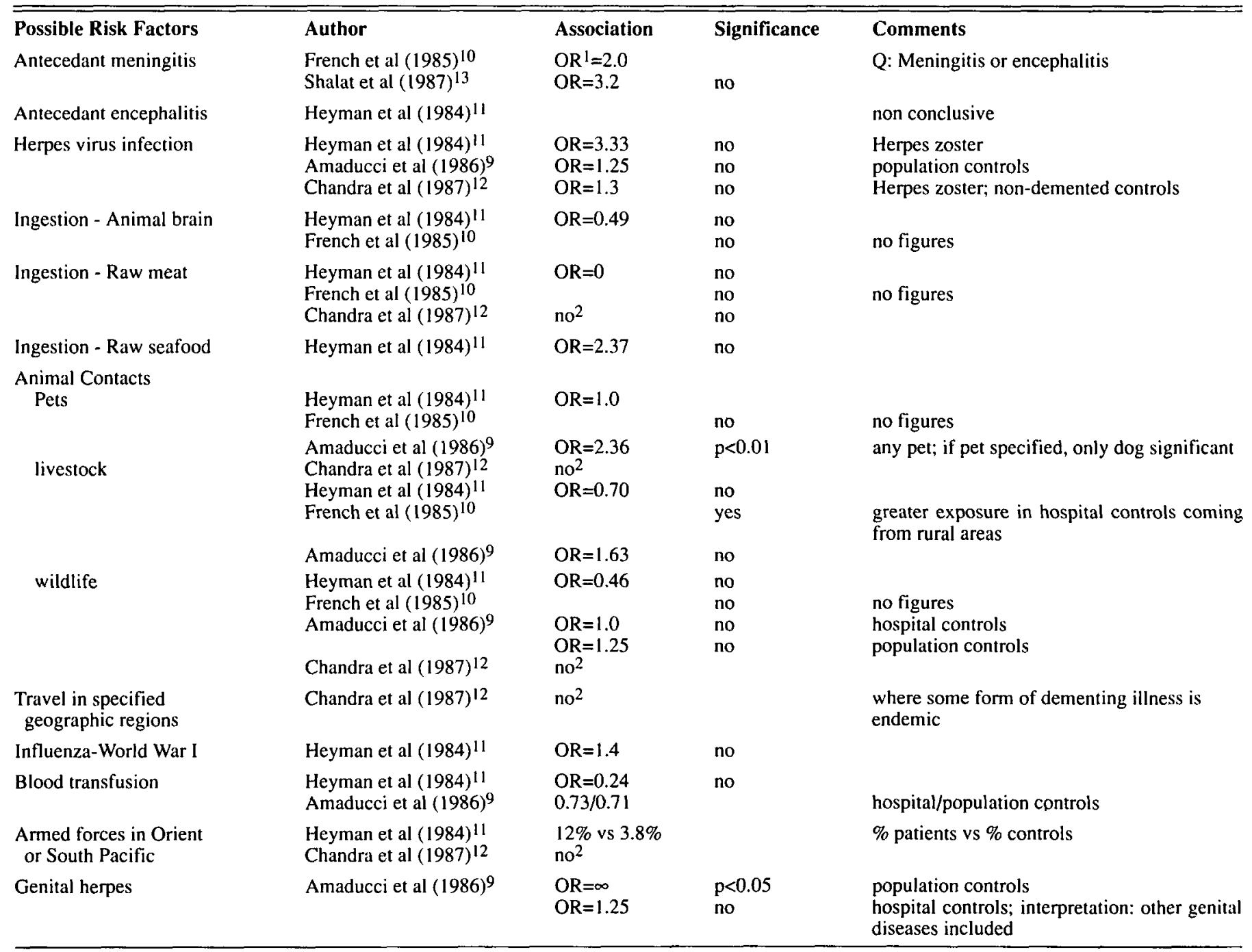


on the critical role of the limbic system in memory, on the involvement of the same region in the histopathology of $\mathrm{AD}$ and on anatomical considerations concerning the innervation from the trigeminal ganglion to the leptomeninges of the subfrontal and medial temporal cortex, areas known to be afflicted during acute herpes encephalitis, Ball suggested that reactivated HSV might travel centripetally through the nucleus of Meynert to cause the degenerative lesions which are common to $\mathrm{AD}$ and normal ageing. In the discussion on the evidence for the involvement of $\mathrm{HSV}$ in $\mathrm{AD}, \mathrm{Esiri}^{8}$ mentioned that reactivation of HSV might be caused by head trauma, a factor shown in epidemiological studies to be associated with AD. 10

\section{Studies on Animal Models}

Animal studies performed to test the hypothesis of the involvement of a common virus or an unconventional virus in AD are summarized in Table 3. The material inoculated into the animals was either a virus (i.e. HSV), brain tissue with scrapie associated fibrils or material from patients with AD or other neurodegenerative disorders including CJD.

Table 2: Studies of Human Brain Tissue to Investigate the Viral Hypothesis of $\mathrm{AD}$

\begin{tabular}{|c|c|c|c|c|c|c|c|}
\hline Authors & Subjects & Virus & Method/Technique & Sensitivity & Material Studied & Outcome & Results \\
\hline \multirow[t]{3}{*}{$\begin{array}{l}\text { Pogo et al } \\
(1987)^{19}\end{array}$} & $18 \mathrm{AD} / 5$ Controls & $\begin{array}{l}7 \text { DNA viruses } \\
4 \text { RNA viruses }\end{array}$ & $\begin{array}{l}\text { Molecular hybridization } \\
\text { \{southern blot }\} \\
\text { \{dot blot }\end{array}$ & & Cerebral cortex & $\begin{array}{l}\text { Viral } \\
\text { DNA } \\
\text { sequence }\end{array}$ & $\begin{array}{l}- \\
+(2 \text { cases; } \\
1 \text { control })\end{array}$ \\
\hline & & Measles & $\begin{array}{l}\text { Molecular hybridization } \\
\text { \{dot blot }\}\end{array}$ & & $\begin{array}{l}\text { RNA extracted } \\
\text { from SI }\end{array}$ & & $+(1$ case $)$ \\
\hline & $8 \mathrm{AD} / 5$ Controls & $\begin{array}{l}3 \text { DNA viruses } \\
5 \text { RNA viruses }\end{array}$ & $\begin{array}{l}\text { Immunocytochemical } \\
\text { techniques for viral antigens }\end{array}$ & & 4 brain regions & & - \\
\hline $\begin{array}{l}\text { Walker et al } \\
(1986)^{23}\end{array}$ & $11 \mathrm{AD} / 4$ Controls & & $\begin{array}{l}\text { Transmission electron } \\
\text { microscopy }\end{array}$ & & $\begin{array}{l}\text { SI } \\
\text { Hippocampus } \\
\text { Temporal cortex } \\
\text { Frontal cortex }\end{array}$ & $\begin{array}{l}\text { Particles } \\
\text { reminiscent } \\
\text { of fully } \\
\text { developed } \\
\text { DNA viruses }\end{array}$ & $\begin{array}{l}\text { only in } \\
\text { AD brains }\end{array}$ \\
\hline $\begin{array}{l}\text { Taylor et al } \\
(1984)^{22}\end{array}$ & $\begin{array}{l}8 \text { Demented/ } \\
9 \text { Controls }\end{array}$ & HSV-1 & Molecular hybridization & $\begin{array}{l}0.1 \text { to } 0.5 \\
\text { genome- } \\
\text { equivalent } \\
\text { of HSV } \\
\text { per cell }\end{array}$ & $\begin{array}{l}\text { (DNA extracts) } \\
\text { Substantia nigra } \\
\text { Putamen } \\
\text { Globus pallidus } \\
\text { Caudate } \\
\text { Olfactory tubercle } \\
\text { Temporal cortex } \\
\text { Amygdala } \\
\text { Hippocampus }\end{array}$ & $\begin{array}{l}\text { viral } \\
\text { genome } \\
\text { present }\end{array}$ & $\begin{array}{l}- \\
- \\
- \\
- \\
- \\
- \\
- \\
-\end{array}$ \\
\hline Esiri $(1982)^{24}$ & $\begin{array}{l}\text { HSV encephalitis } \\
\text { cases/Controls } \\
\text { among which AD }\end{array}$ & HSV & Immunohistochemistry & & $\begin{array}{l}\text { Dentate fascia of } \\
\text { the hippocampus }\end{array}$ & $\begin{array}{l}\text { stained } \\
\text { neurons }\end{array}$ & $\begin{array}{l}+(12 \text { AD) } \\
\text {-(other AD, } \\
\text { other } \\
\text { controls) }\end{array}$ \\
\hline $\begin{array}{l}\text { Mann et al } \\
(1981)^{20}\end{array}$ & $\begin{array}{l}\text { Brains: } \\
12 \mathrm{AD}, 6 \mathrm{PD} \\
8 \text { non-neurological } \\
\text { controls } \\
\text { Temporal lobe } \\
\text { Biopsies: } \\
10 \mathrm{AD}, 5 \text { normal } \\
\text { controls, } 1 \text { control } \\
\text { with HSV } \\
\text { encephalitis }\end{array}$ & HSV & $\begin{array}{l}\text { Immunohistochemistry } \\
\text { Antibody-enzyme (PAP) } \\
\text { method }\end{array}$ & & & $\begin{array}{l}\text { stained } \\
\text { neurons }\end{array}$ & $\begin{array}{l}+(1 \mathrm{AD} \\
\text { biopsy }) \\
-(40 \text { cases })\end{array}$ \\
\hline \multirow[t]{3}{*}{$\begin{array}{l}\text { Sequiera et al } \\
(1979)^{21}\end{array}$} & $\begin{array}{l}6 \text { Psychiatric } \\
\text { patients } \\
\text { (A:4 chronic; B:2 } \\
\text { acute) } \\
\text { \{AD: chronic and } \\
\text { neuropathological } \\
\text { confirmation }\}\end{array}$ & HSV-1 & In situ hybridization & & $\begin{array}{l}\text { Brain smears } \\
\text { (HSV-1 sequence) }\end{array}$ & $\begin{array}{l}\text { Viral } \\
\text { genome } \\
\text { present }\end{array}$ & $\begin{array}{l}+(\mathrm{A}: 3 / 4) \\
-(\mathrm{B}: 2 / 2) \\
+(\mathrm{AD}: 2 / 3)\end{array}$ \\
\hline & $\begin{array}{l}1 \text { Control with HSV } \\
\text { encephalitis }\end{array}$ & & $\begin{array}{l}\text { Solution (nucleic acids) } \\
\text { hybridization }\end{array}$ & $\begin{array}{l}76 \text { genome- } \\
\text { equivalent } \\
\text { of virus DNA } \\
\text { per cell }\end{array}$ & DNA extracts & & + \\
\hline & $\begin{array}{l}\text { Same group of } \\
\text { patients }\end{array}$ & Adenovirus - 7 & & & DNA extracts & $\begin{array}{l}\text { Viral } \\
\text { genome } \\
\text { present }\end{array}$ & $-(A . B)$ \\
\hline
\end{tabular}


Twenty-four weeks after inoculation of HSV-I in the footpad of 53 adult Scofield mice, the viral genome was detected in brain sections by in situ hybridization. The virus itself could not at that time be detected in tissue culture or by using immunofluorescence. ${ }^{21}$ Brain tissue containing scrapie associated fibrils, now recognized as the scrapie agent, ${ }^{26}$ was inoculated intracerebrally to mice. Alzheimer-like senile plaques (SP) were observed, with amyloid specific to scrapie and were attributable to the infectious agent. ${ }^{27}$ Brain tissue from patients with diseases presumably caused by an infectious agent (i.e. CJD or Gerstmann-Straussler disease) and with neurodegenerative disorders of unknown origin was inoculated intracerebrally to rodents. When marmosets were inoculated with brain tissue from a patient with Gerstmann-Straussler syndrome, spongiform encephalopathy developed similar to what was observed following injection of brain tissue from a patient with CJD. ${ }^{28}$ In young mice inoculated with brain tissue from three CJD patients, one patient with $A D$ and one with Pick's disease, the lifespan was reduced significantly. The similarity of effects observed in mice with inoculum from CJD and $A D$ would suggest that an infectious agent may be associated with $\mathrm{AD}$. Mice inoculated with brain tissue from autopsied patients with multiple sclerosis or with subacute sclerosing panencephalitis had a lifespan similar to that of sham inoculated controls and no neuropathological changes were observed. ${ }^{29}$

It has been proposed that failure to transmit $A D$ to animals might be due to reduced infectivity in intermediate or late stages of the disease. Manuelidis et al ${ }^{30}$ investigated the transmissibility of $A D$ by intracerebral inoculation in hamsters of the buffy coat of blood from 11 relatives of $\mathrm{AD}$ patients, two of whom had mild forms of the disease. After an average incubation time of 352 days, the injected biological material of five individuals produced histologically confirmed spongiform encephalopathy.
The lesions observed were similar to those produced by experimental transmission of CJD. It appeared as if the buffy coat of blood contained a transmissible agent. The nature of the lesions observed has led the authors to suggest that some AD cases might be caused by an infectious agent and that the characteristic lesions seen in AD or in CJD would be due to host factors reacting to such agents (e.g. genetic, immunologic, hormonal and ageing). These results are important but further interpretation awaits replication by other investigators.

\section{Aluminum}

The first reports that neurotoxic concentrations of aluminum (Al) were present in the brains of Alzheimer patients were made by Crapper et al in 197331 and 1976.32 These findings have been described in at least eight different geographical areas: South East Canada, ${ }^{32}$ East Canada and England, ${ }^{33}$ England, ${ }^{34}$ Central USA, ${ }^{35}$ North East USA, ${ }^{36}$ France, ${ }^{37}$ Australia. ${ }^{38}$

This element accumulates in chromatin of the nucleus of tangle-bearing neurons, in protein moieties of NFT, in amyloid core and cerebral ferritin. ${ }^{39} \mathrm{High} \mathrm{Al}$ concentrations have been found in other neurodegenerative diseases in which NFT are a common feature (i.e., Down's syndrome (DS), Parkinsonism-dementia (PD+D), and amyotrophic lateral sclerosis (ALS)). Whether $\mathrm{Al}$ accumulates passively in neurons as a result of disrupted properties of the neuronal membrane, or whether it acts as a pathogenic environmental agent remains controversial. No clear relationship has been established between the known neurotoxic effects of $\mathrm{Al}$ and the neurodegenerative processes in $\mathrm{AD}$. Neurotoxicity of Al can take place through alterations of calcium $(\mathrm{Ca})$ homeostasis. The high concentration of $\mathrm{Al}$ observed in conjunction with high levels of Ca in ALS and PD+D in Guam, as well as the demonstration in animal models that $\mathrm{Al}$-induced

\begin{tabular}{|c|c|c|c|c|c|c|c|}
\hline Author & Animals & Virus/Tissue & Method & Findings: Outcome & \multicolumn{3}{|l|}{ Results } \\
\hline $\begin{array}{l}\text { Baker et al } \\
(1985)^{28}\end{array}$ & Marmosets & $\begin{array}{l}\text { Brain tissue from } \\
1 \text { Gerstmann-Straussler; } \\
1 \text { CJD }\end{array}$ & $\begin{array}{l}\text { Intracerebral inoculation } \\
\text { with brain tissue; electron } \\
\text { microscopy }\end{array}$ & $\begin{array}{l}\text { Transmission of } \\
\text { spongiform } \\
\text { encephalopathy }\end{array}$ & \multicolumn{3}{|c|}{$\begin{array}{l}\text { Hypothesis: the causative } \\
\text { agent is a product of the } \\
\text { human genome }\end{array}$} \\
\hline $\begin{array}{l}\text { Greenham et al } \\
(1985)^{29}\end{array}$ & $\begin{array}{l}\text { Mice } \\
\text { (inoculated vs. } \\
\text { sham inoculated } \\
\text { controls) }\end{array}$ & $\begin{array}{l}\text { Brain tissue from } 3 \text { CJD, } \\
1 \text { AD, } 1 \text { Pick's, } 1 \text { MS, } 2 \\
\text { subacute panencephalitis } \\
\text { with histopathological } \\
\text { confirmation }\end{array}$ & $\begin{array}{l}\text { Intracerebral inoculation } \\
\text { with brain tissue }\end{array}$ & $\begin{array}{l}\text { Lifespan of mice with } \\
\text { inoculum from CJD, } \\
\text { AD, Pick's } \\
\text { Lifespan of mice with } \\
\text { inoculum from MS, } \\
\text { SSPE, control mice }\end{array}$ & \multicolumn{3}{|c|}{$\begin{array}{l}\text { Significant decreased } \\
\text { lifespan } \\
\text { No neuropathological } \\
\text { changes; normal lifespan }\end{array}$} \\
\hline $\begin{array}{l}\text { Wisniewski } \\
\text { et al }(1981)^{27}\end{array}$ & Mice & Scrapie agent & $\begin{array}{l}\text { Intracerebral inoculation } \\
\text { with brain tissue-electron } \\
\text { microscopy }\end{array}$ & $\begin{array}{l}\text { Alzheimer-like changes } \\
\text { in brain: plaques in } \\
\text { "genetically susceptible" } \\
\text { hosts }\end{array}$ & \multicolumn{3}{|c|}{$\begin{array}{l}\text { The formation of plaques } \\
\text { is closely related to } \\
\text { infectious agent; } \\
\text { accompanying blood } \\
\text { brain barrier changes }\end{array}$} \\
\hline $\begin{array}{l}\text { Sequiera et al } \\
(1979)^{21}\end{array}$ & $\begin{array}{l}\text { Adult Schofield } \\
\text { mice } \\
\text { (53 inoculated vs } \\
\text { sham inoculated } \\
\text { controls) }\end{array}$ & HSV-I & $\begin{array}{l}\text { Inoculation in foot-pad } \\
\text { detection of virus by } \\
\text { immuno-fluorescence } \\
\text { and in situ hybridization }\end{array}$ & $\begin{array}{l}\text { HSV-1 in tissue culture } \\
\text { HSV-1 detected by } \\
\text { immuno-fluorescence } \\
\text { HSV nucleic acid } \\
\text { sequence }\end{array}$ & $\begin{array}{c}\text { Controls } \\
- \\
- \\
-\end{array}$ & $\begin{array}{r}\text { C } \\
\text { Wk } 1 \\
+ \\
+ \\
+\end{array}$ & $\begin{array}{c}\text { Ses } \\
\text { Wk } 24 \\
- \\
- \\
+\end{array}$ \\
\hline
\end{tabular}

Abbreviations: HSV: Herpes simplex virus; CJD; Creutzfeld-Jacob disease; AD: Alzheimer's disease; MS: Multiple Sclerosis; SSPE: Subacute sclerosing panencephalitis 
changes in Ca concentrations are related to disturbed electrical activity and development of encephalopathy, suggests that this mechanism might be involved in neurofibrillary degeneration. Abnormal accumulations of $\mathrm{Al}$ in neurons could be explained through disruption of genetically controlled mechanisms for limited uptake, detoxification and clearance of $\mathrm{Al}$.

\section{Case-control Studies}

Two case-control studies have attempted to determine a relationship between $\mathrm{AD}$ and ingestion of aluminum through antacid medication, however, the data collected was uninformative.9.11 Odds ratios obtained through logistic regression 11 or through McNemar's test ${ }^{9}$ were all inferior to 1 and not significant. Kappa statistics were used to assess the reliability of data obtained from surrogate respondants by comparing responses from non-demented controls to those from their next of kin. Heyman et al ${ }^{11}$ found good agreement for questions of drug use and dietary habits. Amaducci et al, ${ }^{9}$ on the other hand, found very poor agreement (less than 60\%) for use of antacid drugs. This approach to assess exposure to $\mathrm{Al}$ may thus be questionable.

\section{Ecological Studies}

In the Western Pacific, increased prevalence of ALS and $\mathrm{PD}+\mathrm{D}$ were found together with elevated levels of $\mathrm{Al}$ in soil and drinking water as well as high levels of $\mathrm{Mn}$ and iron and low levels of $\mathrm{Ca}$ and magnesium $(\mathrm{Mg}) .^{40}$ These findings have raised the possibility that environmental exposure to neurotoxins might be of importance in the etiology of neurodegenerative disorders including $A D$.

Epidemiological studies performed in England 41 and Norway 42 have shown geographical variation in mortality rates from dementia. Significant difference in standardized mortality rate for dementia between the counties of Northumberland and Durham were found, ${ }^{41}$ the rate being higher in Northumberland. The mortality rates were calculated from death certificates for the period 1968-1978. The natural content of water and soil as well as the use of $\mathrm{Al}$ in the treatment of water are suspected to be associated with these differences, however no data were available to test this hypothesis at the time of publication in 1984.

In Norway, ${ }^{42}$ an ecological study was performed relating the mortality rates from dementia to the acidity level of precipitation in five regions in the country and to levels of $\mathrm{Al}$ in waterworks. Environmental exposure to $\mathrm{Al}$ has been increasing with the mobilization of $\mathrm{Al}$ from soil to water as a result of acid precipitation. ${ }^{43}$ The mortality rates were calculated using death certificates on which dementia was listed not as the first but as one of the three other causes of death. A dose-response was found between $\mathrm{Al}$ content in drinking water and mortality rates from dementia.

These results can only suggest a possible relationship between environmental exposures and dementia. No distinction was made between $A D$ and other dementias. The reliability of death certificates to establish rates of $A D$ would be questionable since diagnoses from across the country would unlikely be standardized. A problem related to all ecological studies is the lack of information concerning personal characteristics; hence, duration of exposure in a given geographical area cannot be controlled for.

\section{Hemodialysis and Dementia}

The neurological syndrome known as dialysis encephalopathy (DE) has been described by Alfrey et al ${ }^{44}$ in patients receiving hemodialysis for chronic renal failure. The initial manifestations are intermittent speech difficulties and changes in the EEG consisting of spike and wave complexes. After several months, the clinical manifestations consist of dyspraxia, tremor, myoclonus, loss of memory and personality changes. In the late stages, loss of speech occurs together with motor incoordination and seizure activity. Survival after the onset of the disease is six to nine months. Elevated Al levels have been found in the brain of deceased patients. Aluminum in Al-containing phosphatebinding gels was suspected of being the causative factor since duration of dialysis was related to $\mathrm{Al}$ content in the brain. ${ }^{44}$ Another suspected source of $\mathrm{Al}$ was the water treated with $\mathrm{Al}$. Indeed a relation was observed between the geographical distribution of the disease and the regional water $\mathrm{Al}$ content. ${ }^{45}$

In an epidemiological analysis of DE and $\mathrm{Al}$ exposure, 55 patients developed the syndrome out of 1380 patients at risk from six dialysis centers in the USA. ${ }^{46}$ The survival of these patients was reduced significantly and DE was the first cause of death. The attack rate of DE was $4 \%$ but varying from $2.2 \%$ to $14.7 \%$ across centers. Patients with DE had a significantly higher mean cumulative exposure to $\mathrm{Al}$ through dialysate water than other patients at risk but not afflicted with DE. It was not possible to determine a specific level of $\mathrm{Al}$ cumulative exposure over which patients would be more likely to develop DE. Rather, there was an important overlap of patients with and without DE when cumulative exposure was considered. If average level of exposure was taken into account, there was an increased relationship between the level of $\mathrm{Al}$ exposure and the time for the development of the disease. Differences in attack rates would be due to differences in distribution of $\mathrm{Al}$ in tissues, long term exposure to low levels of $\mathrm{Al}$ being related to deposition of the metal in bones. 47

The high $\mathrm{Al}$ content in brain of patients dying with $\mathrm{DE}$ appears to be concentrated in lysosomes as revealed by $\mathrm{X}$-ray microanalysis. Rat brains injected systemically with Al chloride contain high levels of Al. ${ }^{48}$ The first neuropathological investigations in patients dying with DE did not identify any NFT nor any SP characteristic of AD. ${ }^{49}$ More recently, NFT neuronal degeneration was demonstrated in two patients with DE. 50 NFT were observed in cortical neurons of the neocortex and in the hippocampus. There were no senile plaques (SP) nor any granulovacuolar degeneration. High levels of $\mathrm{Al}$ were measured in tangle-bearing neurons, in whole brain and in blood. The NFT were similar to those found in experimental Al neurotoxicity studies and were therefore different from those seen in AD. The material did not stain with Congo red, was not doubly refractile and stained with antibody to the 210000 Dalton portion of NFT polypeptides.

\section{Occupational Exposure}

No neurotoxic effects of occupational exposure to $\mathrm{Al}$ have been documented in groups of workers. Case reports have been published on health effects of long term exposure to $\mathrm{Al}$.

For many years evidence for neurotoxic effects from occupational exposure to $\mathrm{Al}$ was based on a single case report. ${ }^{51}$ This described a man who had worked for 13 years in an Al powder 
factory. He suffered from extensive $\mathrm{Al}$ fibrosis of the lung and of progressive encephalopathy associated with epileptiform seizures. The brain content of Al was 22 times higher than normal $(22 \times 6 \mu \mathrm{g} \mathrm{Al} / \mathrm{g}$ wet $w \mathrm{t})$. No SP and no NFT were seen at necropsy.

Only recently another case was reported.52 A Japanese man who had worked for 30 years in a refining plant was admitted to hospital at age 60 with a diagnosis of dementia and Balint's syndrome. The first symptoms of dementia were noted at the age of 55 and the patient died at 65 . The neuropathological examination revealed cerebral atrophy mostly in the temporal and occipital lobes. Typical NFT were seen in large numbers in the cerebral cortex, and to a lesser extent in the amygdala and nucleus of Meynert. SP of a primitive nature were present in the cerebral cortex and in the cerebellum which is not a target site in AD. Wavelength-dispersive $\mathrm{X}$-ray microanalysis revealed the presence of $\mathrm{Al}$ in the nuclei and cytoplasm of tangle-bearing neurons.

\section{Biological Markers of Aluminum Exposure in Man and in Animal}

Hair appears to be a good indicator of $\mathrm{Al}$ exposure in controlled experimental studies on rabbits. Although a large variability of $\mathrm{Al}$ content in hair (Al-h) pre- and post-exposure to $\mathrm{Al}$ lactate injection was present, a dose-response relationship was demonstrated in a study by Yokel..$^{53}$

Attempts to determine the Al levels in plasma or serum (Al-p or Al-s) in normal subjects is difficult. Cornelis ${ }^{54}$ has reported that Al-s was less than $10 \mu \mathrm{g} / \mathrm{l}$ in a sample group from the general population. In a review of studies reporting mean levels of Al-s in normal adults, Versiek ${ }^{55}$ found considerable variation. Mean Al-s varied from $3.72 \pm 1.2$ to $240 \mu \mathrm{g} /$ in studies where atomic absorption spectrometry was used and from 25 to $1460 \mu \mathrm{g} / \mathrm{l}$ in studies using neutron activation analysis. It was suggested that variability was attributable to contamination of biological samples with $\mathrm{Al}$ and possibly to real differences in background levels in the areas where studies were performed. Daily ingestion of Al-containing drugs during three days increased the $\mathrm{Al}$ in urine (Al-u) significantly. 56

In a large study performed in Sweden, $\mathrm{Al}$ in blood and in urine (Al-b and $\mathrm{Al}-\mathrm{u}$ ) were measured in 93 workers exposed to $\mathrm{Al}$ in four different types of occupations, in dialysis patients without $\mathrm{DE}$ and in referents. High urinary concentrations were found in dialysis patients and in some occupational groups (welding and production of $\mathrm{Al}$ powder). Blood levels were much higher in dialysis patients than in any other comparison group. Workers involved in the electrolytic production of $\mathrm{Al}$ $(n=30)$ had comparable Al-u and Al-b to those in referents from the same areas. .7

In Italy, a small study was done on a group of seven workers among which four were exposed to $\mathrm{Al}$ fumes and the others to dust. Al-u was the most sensitive indicator of exposure since it distinguished exposed from non exposed workers at low levels of environmental exposure at which Al-p was non informative. Absorption from exposure to fumes was greater than to dust. ${ }^{58}$

Sjogren et al ${ }^{59,60}$ in subsequent studies restricted to welders, identified as the most extensively exposed workers to $\mathrm{Al}$, showed that duration and levels of exposure were related to $\mathrm{Al}-\mathrm{u}$ during a period of typical exposure. The estimated half-time for workers exposed to $\mathrm{Al}$ for more than 10 years suggested that $\mathrm{Al}$ can be stored for long periods of time after cessation of exposure in secondary compartments before being cleared in the urine.

Attempts to demonstrate altered levels of $\mathrm{Al}$ in peripheral tissues have failed. In a study by Shore and Wyatt, ${ }^{61}$ no difference was found between $\mathrm{AD}$ patients and controls in $\mathrm{Al}$ content ii CSF, serum and hair. However, these results are questionable since the study was done only on a small group of subjects, the choice of controls was not always appropriate and the measurements were not all performed in the same laboratory.

\section{Neurotoxic Metals and Trace Elements}

Neurotoxicity of lead, tin, manganese, mercury and zinc as evidenced in case reports or epidemics and as confirmed in animal studies will be reviewed in this section. The basis for their potential involvement in the pathogenesis of AD will be discussed.

\section{Lead}

Organic lead Tetraethyllead is the most common form of organic lead since it was added to gasoline in 1923. This organo compound becomes toxic in vivo after it is metabolized to triethyllead. ${ }^{62}$ Several intoxications have been reported among petrol storage tank cleaners not protected against inhalation. 63 Symptoms resulting from organic lead poisoning are entirely due to an organic brain syndrome. Those who survive the acute phase of intoxication are believed to be free of residual disabilities. However, it has been suggested that heavy exposure may cause permanent brain damage. Cerebral atrophy and loss of neurons in the hippocampus have been observed in the brain of a gasoline sniffer with a history of hallucinations and poor memory possibly attributable to tetraethyllead. ${ }^{63}$

Seawright et al, ${ }^{64}$ have shown that brain lesions following administration of triethyllead in rats are not reversible as previously thought. The lesions affect segments of the hippocampus similar to those affected by trimethyltin (the toxicity of alkyltins will be discussed below). Niklowitz ${ }^{65}$ has described NFT in rabbits intoxicated with tetraethyllead. The NFT were shown in degenerating neurons and consisted of bundles of $200 \mathrm{~A}$ tubules. In two out of 16 animals twisted tubules with a periodicity of $800 \AA$ could be seen. These lesions were located in hydropic degenerating pyramidal cells in the frontal cortex and the hippocampus.

Inorganic lead Inorganic lead has been responsible for lead encephalopathy occurring in children living in the slums. The source was flaking lead paint. The first signs of this syndrome are ataxia and irritability followed by convulsions or coma. Since exposure to high levels of lead are associated with encephalopathy, it has been suggested that persons with chronic exposure at low levels or those who have recovered from severe encephalopathy may be at risk for more subtle neurobehavioural disturbances and mental deterioration. Three cases were reported that would support this hypothesis: the first had survived childhood lead encephalopathy and died at 44 years of age after a period of mental deterioration. The neuropathological examination revealed changes characteristic of $A D$ with high levels of lead in brain tissue. 66 Two other cases were reported of workers with long term occupational exposure to lead. One was 
described as demented 15 years before death. 65 In both cases neuropathological features of AD were observed at autopsy. Hence, there are some findings from case reports and animal experiments suggesting that further investigation of a possible association between organic as well as inorganic lead and AD may be justified.

\section{Tin}

Tin and its alkyl derivatives are being released in the environment due to more extensive industrial use. Clinical observation of human intoxication and experimental animal studies have shown that the trialkyltins are the most toxic tin products and that the CNS is the main target. Tin, like lead and mercury, is biomethylated in the environment to its alkyl form. As for most alkyl species of heavy metals, tin does accumulate in the environment and become biotoxic.

Spontaneous epileptic seizures have been described acutely in humans and animals following accidental exposures. The pattern of cell loss observed following TMT intoxication resembles the neuropathological changes observed in human temporal lobe epilepsy.

In a recently published chapter on the neurotoxicity of alkyltins, Walsh and DeHaven 67 reviewed the cellular neurochemical morphological and physiological effects of triethyltin (TET) and dimethyltin (DMT) as well as their effects on sensory systems and behaviour. The work reviewed was mainly based on laboratory animal experiments. TMT intoxication is known to be associated with: i) cell loss and degeneration of neurons in the hippocampus, the brain stem and the primary sensory cortex; ii) alteration in regional concentrations of neurotransmitters (GABA and Dopamine) and increase in serotonin turnover in selected cerebral areas; iii) functional alterations of the visual, auditory and somato-sensory system; iv) persistent changes in behaviour involving motor activity, operant performance and cognitive function. Involvement of the hippocampus is observed both following acute and subacute exposure; the ultrastructural changes following TMT intoxication have been described by Bouldin et al ${ }^{68}$ and Chang et al. 69

The potential relationship between TMT neurotoxicity and $\mathrm{AD}$ is tenuous and is due solely to the similarity of the cortical area involved, namely the hippocampus (see review by Walsh and DeHaven. 67 To date, according to our current knowledge, there is no data on the long term effects of human exposure to tin or to its alkyl derivatives.

\section{Manganese}

Severe manganese $(\mathrm{Mn})$ intoxication has occurred in men working in Mn mines. ${ }^{70}$ Psychiatric and neurological symptoms caused by long term exposure have been observed in several countries (Chile, Africa, India, Cuba and USA) through mining and industrial exposure. ${ }^{71}$ This syndrome has been described as "manganese madness". A case was reported by Banta and Makesbury 72 with elevated Mn levels in several body tissues (brain, hair, serum, blood), with progressive dementia and an extrapyramidal syndrome. Brain biopsy revealed elevated numbers of NFT and SP. This case had presented with the characteristic syndrome of $\mathrm{Mn}$ intoxication but without any history of occupational exposure to this metal. Environmental exposure to Mn or genetic Mn metabolic dysfunction may have been responsible for the development of this intoxication.
It has been reported that miners with acute $\mathrm{Mn}$ intoxication have low levels of blood, CSF and tissue levels of Mn, whereas workers with chronic intoxication have high levels. ${ }^{73}$ In a study of trace elements in the brain of $14 \mathrm{AD}$ patients and of 28 controls, Mn concentrations were determined with instrumental neutron activation analysis (INAA). No significant difference in Mn content in various brain regions was revealed, the grand mean $\mathrm{Mn}$ concentration was $0.261 \mu \mathrm{g} / \mathrm{g}$ for controls and $0.248 \mu \mathrm{g} / \mathrm{g}$ for $\mathrm{AD}(\mathrm{p}>0.05){ }^{71}$

According to published literature, Mn does not appear to be related to the pathogenesis of $\mathrm{AD}$. However, interests in $\mathrm{Mn}$ are justified primarily since elevated levels of this metal were found in the soil and drinking water in areas where neurodegenerative diseases have a high prevalence ${ }^{40}$ and also because increasing levels of $\mathrm{Mn}$ are available in the environment of industrialized countries. 43

\section{Mercury}

Organic mercury intoxication has been described by Hunter et al. ${ }^{74}$ The clinical syndrome consists of paraesthesiae of the face and of the extremities, ataxia, incoordination and concentric constriction of visual fields. ${ }^{70}$ Environmental exposure to methylmercury has been increasing in industrialized countries during recent decades. Through the action of bacterial microorganisms, inorganic mercury is methylated, then becomes bioavailable and may enter the food chain through fish. Chronic exposure to high levels of methylmercury through high consumption of fish caused an outbreak in Minamata in 1950 and later in Niigata. A major outbreak of organic mercury intoxication resulted from consumption of grains treated with methylmercury used as fungicide. The most important outbreak occurred in 1971-72 in Iraq where 6,000 people were admitted to hospital. In this acute intoxication, a dose-response relationship was demonstrated. ${ }^{75}$ Chronic exposure to lower levels in populations who have a high fish consumption (e.g. Canadians living near large paper manufacturers) has not been shown to produce an incidence of paraesthesiae that would be greater than the background occurrence. It could be that methylmercury metabolism has reached a steady state in those groups of people. ${ }^{75}$ Fetotoxicity has been demonstrated following the outbreak in Iraq. Exposure of pregnant women to methylmercury resulted in fetal abnormalities. The incidence of mental deficiency and cerebral palsy in infants was related to methylmercury absorption as and correlated with measures in hair of the mothers. ${ }^{76}$

In a study of trace elements, brain mercury $(\mathrm{Hg})$ in $14 \mathrm{AD}$ patients was compared to brain $\mathrm{Hg}$ in 28 controls using INAA. Important elevations of $\mathrm{Hg}$ were shown in $\mathrm{AD}$ patients when bulk brain was investigated. ${ }^{77}$ In a study of specific brain areas, a significant increase of $\mathrm{Hg}$ in the nucleus basalis of Meynert was reported in $A D$; however, no imbalance was found in the amygdala nor in the hippocampus. ${ }^{78}$ Determination of $\mathrm{Hg}$ in hair and nails with INAA in $180 \mathrm{AD}$ and control subjects showed no imbalance in hair levels and significantly decreased levels of $\mathrm{Hg}$ in nails of $\mathrm{AD}$ patients.

Brain damage due to $\mathrm{Hg}$ poisoning is limited to specific areas: the granule cells of the cerebellum and neurons in the visual cortex. Methylmercury has been shown to inhibit protein synthesis in the brain. Experimental work in rats has shown that cells from different parts of the brain are affected but recover 
except the cells in the identified target areas (reviewed by Clarkson). ${ }^{80}$

The human brain is more susceptible to methylmercury poisoning during the early months of life, since methylmercury affects cell division and cell migration in the developing brain. ${ }^{81}$

Apart from the reported imbalances in tissue levels of $\mathrm{Hg}$ in $\mathrm{AD}$ patients compared to normal subjects, there is no evidence to date that $\mathrm{Hg}$ is involved in the pathogenesis of $\mathrm{AD}$. The clinical signs of $\mathrm{Hg}$ intoxication do not resemble those of $\mathrm{AD}$, the brain regions involved in $\mathrm{Hg}$ poisoning are the same as those affected in $\mathrm{AD}$, and no neuropathological changes characteristic of $\mathrm{AD}$ have been reported.

\section{Zinc}

It has been postulated by Burnet ${ }^{82}$ that zinc $(\mathrm{Zn})$ deficiency might be important in the pathogenesis of $A D$ as well as other disorders such as epilepsy and schizophrenia through depression of DNA and RNA metabolism. Ehmann et al 77 found no difference between AD cases and controls in the $\mathrm{Zn}$ content of brain bulk samples from the cortex. However, the same group of workers found elevated levels of $\mathrm{Zn}$ in the amygdala. ${ }^{78} \mathrm{Ward}$ et al, ${ }^{3}$ found decreased $\mathrm{Zn}$ levels in $\mathrm{AD}$ hippocampus and cerebral cortex. Markesbery and Ehmann, 83 in a pilot study using energy dispersion X-ray microprobe analysis with transmission or scanning electron microscope, have not observed high $\mathrm{Zn}$ concentrations in tangle-bearing or tangle-free neurons. Depressed serum levels in $\mathrm{Zn}$ have been reported in $\mathrm{AD}$ patients. ${ }^{84}$ Elevated levels have been found in hair and nails by Vance et al using INAA. ${ }^{79}$

A detailed review of the effects of $\mathrm{Zn}$ intake and metabolism on brain function in animal models was recently published by Wallwork. ${ }^{84}$ The author examined the interrelationship between $\mathrm{Zn}$ intake and essential or toxic elements. Perinatal brain damage due to $\mathrm{Zn}$ deficiency is reported to be permanent. Neurochemical investigations have shown that $\mathrm{Zn}$ alters normal nucleic acid and protein synthesis including cytostructural protein and affects the metabolism of neurotransmitters (GABA and catecholamines).

In conclusion, there is some evidence, although very limited, that some of the metals mentioned above may be related to AD. Detailed epidemiological studies are required to substantiate the evidence based on a few case reports and animal studies. Two approaches could be considered: cohort studies of workers with a history of long term exposure to one of these metals, or casecontrol studies of AD in relation to past exposure to these substances. Differences in measured levels of these toxins in tissues of patients and of controls may reflect differential exposure or may indicate genetic or acquired differences in the ability to metabolize or detoxify the toxins.

\section{NeUrotoxins of Biological Origin}

No association, to our knowledge, has been shown between neurotoxins of biological origin and AD. However, a number of amino acids have been suspected to be involved in other neurodegenerative disorders. A recent publication by Martyn ${ }^{85}$ reports three types of intoxications in relation to eating habits in developing countries and to drug consumption. A variety of peas (Lathyrus sativa) found in Africa and in some parts of Asia, and consumed in large quantities during famine, has been associated with Lathyrism, a disorder of the corticospinal tract. The suspected neurotoxin is beta- $\mathrm{N}$ - oxalylamino- $\mathrm{L}$-alanine. This amino acid fed to monkeys induces the same symptoms as those produced by ingestion of the pea. This substance belongs to a group of non-protein amino acids present in food and fungi. The toxin acts on specific membrane receptors, and the neurotoxic effect is due to repeated excitation of neurons.

Beta- $\mathrm{N}$-methylamino-L-alanine produces in monkeys a syndrome similar to ALS and PD+D. This amino acid is present in cycad seeds (Cycas circinalis) which were consumed in large quantities, up until World War II, by Chamorros of Guam and Rota. First mention of the possible association between cycad seed consumption and ALS as well as PD+D was made in 1979 by Reed and Brody. 86

Another example of a specific neurotoxic effect is the development of parkinsonism in drug abusers who injected synthetic opiates contaminated with 1-methyl-4-phenyl1,2,3,6-tetrahydropyridine (MPTP), a substance active against dopaminergic neurons. ${ }^{87}$

An outbreak of illness following Prince Edward Island mussels consumption occurred in the fall in 1987. The syndrome was characterized by confusion and disorientation followed by depression of consciousness and seizures. In some of the patients surviving the acute episode, a residual syndrome developed consisting of anterograde memory deficits without global intellectual impairment, and clinical as well as electromyographic evidence of motor neuropathy. Histopathological examination of the brains of three patients dying as a result of the intoxication revealed bilateral lesions of the hippocampus and the amygdala. Patients over the age of 75 exhibited generalized intellectual impairment. Domoic acid has been identified as the neurotoxin responsible for the outbreak. It is a glutumate analog structurally similar to kainate, an excitatory amino acid. Kainic acid has been shown to produce similar effects to the mussels intoxication in animal models and to produce cell degeneration in the olfactory cortex, the amygdala and the hippocampus. Mechanisms of neurotoxicity are unknown, but domoic acid may affect pre- and post-synaptic binding sites and affect calcium uptake. 88

\section{IMMUNE SySTEM DySFUnCTION}

\section{Case-Control Studies of Alzheimer's Disease in Relation to Diseases of the Immune System}

In Finland, Soininen and Heinonen 89 in a study of the clinical aspects of $\mathrm{AD}$ in $63 \mathrm{AD}$ patients and 91 controls found that the beta-globulin fraction of cerebrospinal fluid was reduced in electrophoresis in AD patients compared to controls. However, IgG and albumin levels in cerebrospinal fluid and serum were not significantly different.

Findings by Heston et al 90 in the families of AD cases have established the presence of lymphomas, lymphosarcomas, Hodgkin's disease and affection of the immune system. An increased occurrence of lymphoma was found in first degree relatives of cases with early onset dementia. No increased frequency of leukemia was found in first and second degree relatives of AD cases $(3.1 / 1,000)$ when comparison was made with the expected rate $(4.5 / 1,000) .91$ In a study published by Bharucha and Schoenberg92 no association was reported between $A D$ and 
potential immune disorders (e.g. lymphoma, leukemia, post-tonsillectomy) in 53 patients compared to 53 controls. Chandra et al ${ }^{12}$ found no association between late onset $A D$ and haematological malignancies in first degree relatives in a study of 64 cases with late onset AD (age $>70$ years) and 64 controls matched for age.

In an investigation of allergic conditions that may reflect an altered immune system (e.g. hay fever, food allergy, drug allergy, contact dermatitis) there was no significant odds ratio when cases were compared to age- sex- and race-matched controls. ${ }^{10}$ In an Italian case-control study, immunologic factors were investigated in 153 cases and the same number of hospital and population controls. Allergic dermatitis was more frequent in $A D$ than in hospital controls $(O R=2.18, p=0.04)$. No significant OR was found for asthma, allergic rhinitis nor leukemia. ${ }^{9}$ In Boston, no excess of hay fever or other kind of allergy was found in cases ( $n=98$ men) or in their family as compared to controls $(n=162)$ matched for sex, date of birth and town of residence and their family. ${ }^{13}$

Initial findings of Heston et al ${ }^{89}$ of increased frequency of lymphomas in relatives of AD patients have not been replicated in subsequent case-control studies. ${ }^{12,90,81}$ No definite conclusion can be proposed concerning the association between AD and allergic conditions.

\section{Studies of Cellular Immune Activity in Patients with AD}

A Study of B-cell function revealed increased $\operatorname{IgM}$ in presenile AD. ${ }^{93}$ On the other hand, $\operatorname{IgA}$ and $\operatorname{IgG}$ were not increased as compared to older controls in whom, however, the immunoglobulins (Ig) were elevated compared to younger normal controls. The Ig kappa/lambda ratio was also normal. In the same study, evaluation of serum electrophoresis indicated that Ig was not monoclonal. C3 complement function was unchanged. In the investigation of the possible association between $\mathrm{AD}$ and markers of the complement component $\mathrm{C} 2$ and $\mathrm{C} 4$ in the Calabrese family extensively studied by Foncin ${ }^{92}$ the results were negative. Complement components $\mathrm{C} 2$ and $\mathrm{C} 4$ are associated with the major histocompatibility complex.

Early studies of autoimmunity in AD indicated that the presence of auto-antibodies was not an important feature in this disorder. Clinical signs of altered immunity could not be demonstrated, but the presence of brain auto-antibodies was not investigated. ${ }^{94}$ Recently, antibodies specifically binding to rat brain tissue sections were demonstrated in sera from patients with AD. 95 In this study, sera from $30 \mathrm{AD}$ patients were compared to sera from 65 controls. Brain antibodies were present in $57 \%$ of $\mathrm{AD}$ and $8 \%$ of other disease controls and were absent in normal controls. The control group included normal adults, normal aged individuals, and patients with Parkinson's disease, multiple sclerosis, Down Syndrome or schizophrenia. The high frequency of anti-brain antibodies in $\mathrm{AD}$ sera was not related to the ageing process, a finding only partly in accordance with previous work. The nature of the antigen has not been characterized.

The investigation of T-cell function showed a non significant decrease in percent and total $T$ lymphocytes in presenile AD.93 Using a pokeweed mitogen (PWM)-induced IgG secretion assay, T8-cell-mediated suppressor function was lower in senile dementia of the Alzheimer type as compared to age-matched controls. These changes may reflect changes of intrinsic lymphocyte properties or neural influences on lymphocytes. ${ }^{96}$
DNA synthesis in lymphocytes from AD patients was reduced in response to phytohemagglutinin (PHA), PWM and OKT3 monoclonal antibody to T3 antigen. The reduction was significant for PHA and PWM when comparison was made with healthy age-matched controls. All subjects were non-institutionalized, they were not taking drugs and had no symptoms of infection at the time of blood sampling. Previous studies of DNA synthesis with radio-labelled nucleotides did not show any decrease among $\mathrm{AD}$ patients. ${ }^{97,98} \mathrm{~A}$ possible explanation of the negative findings in the earlier studies may be that the cases were at different stages of the disease and that no record was kept of drug use of disease status of the subjects. No difference was found in the proportion of cells from AD patients staining positive for surface membrane orosomucoid, the glycoprotein inducing stimulation of human lymphocytes.

Agents responsible for immune disorders might be contributing factors in the genesis of AD. Such an hypothesis was proposed for the metal asbestos by Bianchi et al ${ }^{99}$ who have described $\mathrm{AD}$-type lesions in the brains of 10 cases of malignant pleural mesothelioma or asbestosis due to asbestos exposure in the shipbuilding industry. The immune status of persons with asbestos related disorders is thought to be disturbed. Asbestos could be responsible for hyperactive B-cell function and defective cell-mediated immunity. Yet, the preliminary findings published by Bianchi et al ${ }^{99}$ need to be corroborated in subjects with a more thorough clinical investigation of the disease since none of the cases reported had had a clinical diagnosis of AD. Severe memory impairment among four cases and moderate memory loss in a further case were documented by relatives and had occurred during the last years before death. The assumption that these subjects were suffering from $A D$ was based primarily on the neuropathological investigations showing the presence of $\mathrm{SP}$ in the neocortex in all cases and in the hippocampus of eight brains (although in very limited amount in four of them) and on the presence of NFT in seven cases. It would be of interest to determine the frequency of AD among cases of asbestos-related disorders as well as among asbestos workers, since to our knowledge, this has not been investigated.

The studies summarized above have shown that a number of immune parameters are affected in presenile dementia and AD. This constitutes further evidence that immunological dysfunction might be involved in the pathogenesis of $\mathrm{AD}$.

\section{Conclusion}

There is strong evidence at present for genetic factors to be involved in the pathogenesis of $\mathrm{AD}$. The pattern of inheritance appears to be consistent with an autosomal dominant mode of transmission with incomplete penetrance. ${ }^{100}$ According to a statistical model published by Mohs et al, ${ }^{101}$ the risk of developing AD would reach $50 \%$ in first degree relatives of cases if they lived to 90 years of age. The absence of confirmatory data for such a model would be due to competing causes of death afflicting relatives of late onset $A D$ cases or to the difficulty of making a differential diagnosis in the more elderly siblings of probands.

Transmission of altered genetic material could directly cause the development of $\mathrm{AD}$, or alternatively could be responsible for an increased susceptibility to one or more etiological agents including neurotrophic viruses, neurotoxins or environmental chemicals. 
A hypothesis can thus be formulated according to which exposure to environmental factors in genetically predisposed individuals would occur several years before the onset of the clinical manifestations of the disease. The agent(s) would specifically affect neurons in areas involved in AD (basal forebrain, associative neocortex) or neurons sending projections to these areas. A functional deficit would be latent for several years and would manifest itself as cell loss secondary to disease and ageing reaches a threshold. This hypothesis would be compatible with delayed or progressive cognitive deterioration that would occur subsequent to: i) a viral infection in early life, or ii) chronic exposure to biological neurotoxins naturally occurring in food or beverages consumed on a regular basis; or iii) exposure to neurotoxic metals increasingly prevalent in the environment and becoming more bioavailable in drinking water and in the food chain.

\section{ACKNOWLEDGEMENTS}

This work was supported by the Laboratory Centre for Disease Control, Health and Welfare Canada. We thank Sandra Kogan and Donna Amyot for their help as research assistants and Neil Cashman for his help as consultant.

\section{REFERENCES}

1. Gajdusek DC. Unconventional viruses and the origin and disappearance of kuru. Science 1977; 197: 943-960.

2. Masters CL, Gajdusek DC, Gibbs CJ Jr. The familial occurrence of Creutzfeldt-Jakob disease and Alzheimer's disease. Brain 1981; 104: 535-558.

3. Roos RP. Alzheimer's disease and the lessons of transmissible virus dementia. In: Mortimer JA, Shuman LM, eds. Epidemiology of Dementia. Oxford University Press, New York, 1981; 73-86.

4. Goudsmith J, Morrow CH, Asher DM, Yanagihara RT, et al. Evidence for and against transmissibility of Alzheimer disease. Neurology 1980; 30: 945-950.

5. De Boni V, Crapper DR. Paired helical filaments of the Alzheimer type in cultured neurons. Nature 1978; 271: 566-568.

6. Prusiner SB, et al. Some speculations about prions, amyloid and Alzheimer's disease. New Engl J Med 1984; 310: 661-663.

7. McGeer PL, McGeer EG, Kamo H, et al. Positron emission tomography and the possible origins of cytopathology in Alzheimer's disease. Prog Neuropsych Biol Psych 1986; 10: 501-518.

8. Esiri MM. Typical and atypical viruses in the aetiology of senile dementia of the Alzheimer type. Interdisciplinary Topics Gerontol 1988; 25: 119-139.

9. Amaducci LA, Fratiglioni L, Rocca WA, et al. Risk factors for clinically diagnosed Alzheimer's disease: a case control study of an Italian population. Neurology 1986; 36: 922-931.

10. French RL, Schuman LM, Mortimer JA, Hutton JT, Boatman RA, Christians B. A case control study of dementia of the Alzheimer type. Am J Epi 1985; 121: 414-421.

11. Heyman A, Wilkinson WE, Stafford JA, Helins MJ, Sigmon AH, Weinber T. Alzheimer's disease: a study of epidemiological aspects. Ann Neurol 1984; 15: 335-41.

12. Chandra V, Philipose RN, Bell PA, Lazaroff A, Schoenberg BS. Case control study of late onset "probable Alzheimer's disease". Neurology 1987; 37: 1295-1300.

13. Shalat SL, Seltzer B, Pidcock C, Baker EL. Risk factors for Alzheimer's disease: a case control study. Neurology 1987; 37: 1630-1633.

14. Lycke E, Norsby R, Roos B. A serological study on mentally ill patients with particular reference to the prevalence of herpes virus infections. Br J Psych 1974; 124: 273-9.

15. Lord A, Sutton RNP, Baker AA, Hussein SMA. Serological studies in the elderly. Age and Ageing 1978; 7: 116-22.
16. Whalley LJ, Urbaniak SJ, Darg C, et al. Histocompatibility antigens and antibodies to viral and other antigens in Alzheimer pre-senile dementia. Acta Psychr Scand 1980; 61: 1-7.

17. Renvoize EB, Wad LO, Hambling MH. A sero-epidemiological study of conventional infectious agents in Alzheimer's disease. Age and Ageing 1987; 16:311-314.

18. McKhann G, Drachman D, Folstein M, et al. Report of the NINCDS-ADRDA work group under the auspices of the Department of Health and Human Services Task Force on Alzheimer's disease. Neurology 1984; 34: 939-944.

19. Pogo BGT, Casals J, Elizan TS. A study of viral genomes and antigens in brains of patients with Alzheimer's disease. Brain 1987; 110: 907-915.

20. Mann MA, Yates PO, Davies JS, Hawkes J. Viruses, parkinsonism and Alzheimer's disease. J Neurol Neurosurg and Psych $1981 ; 44: 651$.

21. Sequiera LW, Jennings LC, Carasco LH, Lord M, Curry A, Sutton RNP. Detection of herpes simplex viral genome in brain tissue. Lancet $1979 ; 2$ : 609-12.

22. Taylor GR, Crow TJ, Markakis DA, Lofthouse R, Neeley S, Carter GI. Herpes simplex virus and Alzheimer's disease: a search for virus DNA by spot hybridization. J Neurol Neurosurg and Psych 1984; 47: 1061-1065.

23. Walker D, O'Kusky JR, McGeer PL, McGeer EG. Hybridization analyses of Alzheimer's brains for herpes virus DNA. Society for Neuroscience Abstracts, 1987; 13: 1327.

24. Esiri MM. Viruses and Alzheimer's disease. J Neurol Neurosurg and Psych 1982; 45: 759.

25. Ball MJ. Limbic predilection in Alzheimer's dementia: is reactivated herpes virus involved? Can J Neurol Sci 1982; 9: 303306.

26. Merz PA, Somerville RA, Wisniewski HM. Abnormal fibrils from scrapie-infected brain. Acta Neuropathol (Berl) 1981; 54: 6374.

27. Wisniewski HM, Moretz RC, Lossinsky AS. Evidence for induction of localized amyloid deposits and neuritic plaques by an infectious agent. Ann Neurol 1981; 10: 517-522.

28. Baker HF, Ridley RM, Crow TJ. Experimental transmission of an autosomal dominant spongiform encephalopathy: does the infectious agent originate in the human genome? Br Med J $1985 ; 291: 299-302$.

29. Greenham LW, Peacock DB. Comparison of survival times of mice inoculated with brain tissue from various neurological diseases. Ann Neurol 1985; 17: 206-209.

30. Manuelidis E, de Figueiredo IM, Kim JE. Transmission studies from blood of Alzheimer's disease patients and healthy relatives. Proc Natl Acad Sci 1988; 85: 4898-4901.

31. Crapper DR, Daltor AJ. Aluminum induced neurofibrillary degeneration, brain electrical activity and alterations in acquisition and retention. Physiol Behav 1973; 10: 935.

32. Crapper DR, Krishnan SS, Quittkat S. Aluminum neurofibrillary degeneration in Alzheimer's disease. Brain 1976; 99: 67-80.

33. Ward WI, Mason JA. Neutron activation analysis for identifying elemental status in Alzheimer's disease. J Radional Nucl Chem 1987; 11: 515-526.

34. Candy JM, Klinowski RA, Perry EK. Aluminosilicates and senile plaques formation in Alzheimer's disease. Lancet 1986; 1: 353 356.

35. Trapp GA, Milner GD, Zimmerman RL, et al. Aluminum levels in brain in Alzheimer's disease. Biol Psychiatry 1978; 13: 709.

36. Perl DP, Brody AR. Alzheimer's disease: spectrometric evidence of aluminum accumulation in neurofibrillary tangle-bearing neurons. Science 1980; 208; 297.

37. Duckett S, Galle P. C.R. Mise en évidence de l'aluminum dans les plaques séniles de la maladie d'Alzheimer: étude à la microsonde de Castaing. Acad Sci [D] (Paris) 1976; 282(4): 293-5.

38. Masters CL, Multhaup G, Simons G, et al. Neuronal origin of a cerebral amyloid: neurofibrillary tangles of Alzheimer's disease contain the same protein as the amyloid of plaque cores and blood vessels. Embo J 1985; 4: 2757.

39. Krishnan SS, McLachlan DR, Krishnan B, et al. Aluminum toxicity to the brain. Sci Tot Environ 1988; 71: 59-74. 
40. Garruto RM, Fukatsu R, Yanagihara R, et al. Imaging of calcium and aluminum in neurofibrillary tangles-bearing neurons in parkinsonism dementia of Guam. Proc Natl Acad Sci USA 1984; 81: 1875-1879.

41. Gardner MJ, Winter PD, Barker DJP. Atlas of mortality from selected diseases in England and Wales 1968-78. Wiley, Chichester, 1984: 62-63.

42. Vogt T. Water quality and health: study of a possible relation between aluminum in drinking water and dementia. Sosiale og. Okonomiske Studier no. 61, 1986; Norwegian Government.

43. Nodberg GF, Goyer KA, Clarkson TW. Impact of effects of acid precipitation in toxicity and metals. Environ Health Persp 1985; 63: 169-180.

44. Alfrey AC, LeGendre GR, Kaehney WD. Dialysis encephalopathy syndrome: possible aluminum intoxication. $N$ Engl $J$ Med 1976; $294: 184$.

45. Elliott HL, MacDougall AI. Aluminum studies in dialysis encephalopathy. Proc Eur Dial Transplant Assoc 1978; 15 : 157.

46. Schreeder MT, Favero MS, Hughes JR, et al. Dialysis encephalopathy and aluminum exposure: an epidemiological analysis. J Chron Dis 1983; 36(8): 581-593.

47. Ward $M$. Dialysis dementia and bone disease in Great Britain. Symp dialysis dementia and aluminum toxicity, Chicago, 1978.

48. Galle P, Berry JP, Duckett S. Electron microprobe ultrastructural localization of aluminum in rat brain. Arch Neuropathol 1980; 49: 245 .

49. Buge A. Encéphalopathie prolongée et reversible chez un dialysé chronique. Responsabilité probable des sels d'aluminium. Nouv Presse Med 1978; 7: 2053.

50. Scholtz CL, Swash M, Gray A, et al. Neurofibrillary neuronal degeneration in dialysis dementia: a feature of aluminum toxicity. Clin Neuropathol 1987; 6(3): 93-97.

51. McLauglin AIG, Kazantzis G, King E, Teare D, Porter RJ, Owen R. Pulmonary fibrosis and encephalopathy associated with the inhalation of aluminum dust. $\mathrm{Br} \mathrm{J}$ Ind Med 1962; 19: 253.

52. Kobayashi S, Hirota N, Saito K, Utsuyama M. Aluminum accumulation in tangle-bearing neurons of Alzheimer's disease with Balint's syndrome in a long term aluminum refiner. Acta Neuropathol (Berl) 1987; 74: 47-52.

53. Yokel RA. Hair as an indicator of excessive aluminum exposure. Clin Chem 1982; 28/4: 662-665.

54. Cornelis R. Variability in reported plasma Al-concentrations. In: CEC Luxembourg 1982.

55. Versiek J, Cornelis R. Measuring aluminum levels. New Eng $\mathbf{J}$ Med 1980; 302(8): 468.

56. Kaehny WD, Hegg AP, Alfrey AC. Gastrointestinal absorptions of aluminum from aluminum-containing antacids. $\mathrm{N}$ Engl $\mathrm{J}$ Med 1977; 296: 389-94.

57. Sjogren B, Lundberg I, Lidums V. Aluminum in the blood and urine of industrially exposed workers. Br J Ind Med 1983; 40: 301-304.

58. Mussi L, Calzaferri G, Buratti M, Alessio L. Behaviour of plasma and urinary aluminum levels in occupationally exposed subjects. Int Arch Occup Environ Health 1984; 54: 115-161.

59. Sjogren B, Lidums V, Hakansson M, Heldstrom L. Exposure and urinary excretion of aluminum during welding. Scand $\mathbf{J}$ Work Environ Health 1985; 11: 39-43.

60. Sjogren B, Elinder CG, Lidums V, Chang G. Uptake and urinary excretion of aluminum among workers. Int Arch Occup Environ Health 1988; 60: 77-79.

61. Shore D, Wyatt JW. Aluminum and Alzheimer's disease. J Nerv Ment Dis 1983; 171: 553-558.

62. Cremer JE. Biochemical studies on the toxicity of tetraethyl lead and other organo-lead compounds. Br J Ind Med 1959; 16: 191-9.

63. Cassells DAK, Dodds EC. Tetraethyl lead poisoning. Br J Med 1946; 2: 681-5.

64. Seawright AA, Brown AW, Aldridge WW, Verschoyle RD, Street BW. In: Holmstedt B, Lawreys R, Mercier M, Robertford M, eds. Mechanisms of toxicity and hazard evaluation. Elsevier/Worth Holland Biomedical Press, Amsterdam, 1980; 71.

65. Niklowitz WJ. Neurofibrillary changes after acute experimental lead poisoning. Neurology 1975; 25: 927-934.
66. Niklowitz WJ, Mandybur TI. Neurofibrillary changes following childhood lead encephalopathy: case report. J Neuropathol Exp Neurol 1975; 34: 445-455.

67. Walsh TJ, DeHaven DL. Neurotoxicity of alkyltins. In: Bondy SC, Prasad KN, eds. Metal neurotoxicity. CRC Press, Inc. 1988.

68. Bouldin TH, Goines ND, Bagnell CR, et al. Pathogenesis of trimethyltin neuronal toxicity: Ultrastructural and cytochemical observations. Am J Pathol 1981; 104: 237.

69. Chang LW, Tiemeyer TM, Wenger GR, et al. Neuropathology of trimethyltin intoxication II. Electron microscopy of the hippocampus. Environ Res 1982; 29: 445.

70. LeQuesne PM. Metal induced diseases of the nervous system. $\mathrm{Br}$ J Hosp Med 1982; 534-538.

71. Markesbery WR, Ehmann WD, Hossain T, Alauddin M. Brain manganese concentrations in human aging and Alzheimer's disease. Neurotoxicology 1984; 5: 49-57.

72. Banta RG, Markesbery WR. Elevated manganese levels associated with dementia and extrapyramidal signs. Neurology 1977; 27: $213-216$

73. Cotzias GC, Horiuchi K, Fuenzalida S, Mena I, Chronic manganese poisoning: clearance of tissue manganese with persistence of the neurologic picture. Neurology 1968; 18: 376-382.

74. Hunter D, Bomford RR, Russell DS. Poisoning by methylmercury compounds. Q J Med 1940; 9: 193-213.

75. Clarkson TW, Smith JC, Marsh DO, Turner MD. A review of dose-response relationships resulting from human exposure to methylmercury compounds. In: Krenkel PA, ed. Heavy metals in the aquatic environment. Oxford: Pergamon Press, 1975; 112.

76. LeQuesne PM. Toxic substances and the nervous system: the role of clinical observation. J Neurol Neurosurg and Psych 1981; 44: $1-8$

77. Ehmann WD, Markesbery WR, Alauddin M, Hossain T, Brubaker EH. Brain trace elements in Alzheimer's disease. Neurotoxicology 1986; 7: 197-206.

78. Thompson CM, Markesbury WR, Ehmann WD, Mao YX, Vance DE. Regional brain trace element studies in Alzheimer's disease. Neurotoxicology 1988; 9: 1-8.

79. Vance DE, Ehmann WD, Markesbery WR. Trace elements imbalances in hair and nails of Alzheimer's disease patients. Neurotoxicology 1988; 2: 197-208.

80. Clarkson TW. Metal toxicity in the central nervous system. Environ Health Persp 1987; 75: 59-64.

81. Choi BH, Lapham LW, Amin-Zaki L, Saleem T. Abnormal neuronal migration, deranged cerebral cortical organizations and diffuse white matter astrocytosis of human fetal brain: a major effect of methyl mercury poisoning in vitro. $J$ Neuropath Exp Neurol 1978; 37: 719-733.

82. Burnet FM. A possible role of zinc in the pathology of dementia. Lancet 1981; 1: 186-188.

83. Markesbery WR, Ehmann WD. Trace elements in dementing disorders. In: Montey JE, Sterman MB, Walsh JM, eds. Nutritional modulation of neural function. San Diego Academic Press, 1988; 179-190.

84. Wallwork JC. Zinc and the central nervous system. Progress in food and nutrition. Science 1987; 11: 203-247.

85. Martyn CN. Neurobiological clues from environmental neurotoxins. Brit M J 1987; 295: 346-347.

86. Reed DM, Brody JA. Amyotrophic lateral sclerosis and parkinsonism dementia on Guam. Am J Epidemiol 1975; 101: 287. 301.

87. Langston JW, Ballard P. Parkinsonism induced by MPTP: implications for treatment and the pathogenesis of Parkinson's disease. Can J Neurol Sci; 1984; 11 (Suppl): 160-105.

88. Teitelbaum JS, Zatorre RJ, Carpenter S, et al. Neurological sequelae of domoic acid intoxication due to ingestion of mussels from Prince Edward Island. Submitted for publication, 1988.

89. Soininen H, Heinonen OP. Clinical and etiological aspects of senile dementia. Env Neurol 1982; 21: 401-410.

90. Heston L, Mastri AR, Anderson E, White J. Dementia of the Alzheimer's type: clinical genetics, natural history and associated conditions. Arch Gen Psychiatry 1981; 38: 1085-1090. 
91. Heyman A, Wilkinson WE, Horwitz BJ, et al. Alzheimer's disease: genetic aspects and associated clinical disorders. Ann Neurol 1983; 14: 507-515.

92. Bharucha NE, Schoenberg BS, Kokmen E. Dementia of Alzheimer's type (DAT): a case-control study of association with medical conditions and surgical procedures. Neurology (NY) 1983; 33: 85.

93. Tavolato B, Argentiero V. Immunological indices in presenile Alzheimer's disease. J Neurol Sci 1980; 46: 325-331.

94. Clemenceau S, Foncin JF, Muller JY, et al. Génétique. Absence de liaison entre la maladie d'Alzheimer et les marqueurs du complement. C R Acad Sci (Paris) 1986; T303, no. 5.

95. Singh VK, Fudenberg HH. Detection of brain autoantibodies in the serum of patients with Alzheimer's disease but not Down's syndrome. Immunol Lett 1986; 12: 277-280.

96. Skias D, Baria M, Reder AT, et al. Senile dementia of Alzheimer's type (SDAT): reduced T8+-cell mediated suppressor activity. Neurology 1985; 35: 1635-1638.
97. McDonald SM, Goldstone AH, Morris JE, et al. Immunological parameters in the aged and in Alzheimer's disease. Clin Exp Immunol 1982; 49: 123-128.

98. Watts HF. Investigations into an immunological component in Alzheimer's disease. Interdiscip Top Gerontol 1985; 19: 54-61.

99. Bianchi C, Bittesini L, Brollo A. Asbestos exposure and Alzheimer's disease. Ital J Neurol Sci 1986; 7: 145-151.

100. Foncin JF, Salmon D, Supino-Viterbo V, et al. Alzheimer's presenile dementia transmitted in extended kindreds. Rev Neurol (Paris) 1985; 141(3): 194-202.

101. Mohs RC, Breitner JCS, Silverman JM, Davis KL. Alzheimer's disease. Morbid risk among first-degree relatives approximates $50 \%$ by 90 years of age. Arch Gen Psychiatry 1987; 44: 405408. 